ment. One of us (H. L.) would like to thank the Federal and Eastern Region Governments, Nigeria, for defraying the cost of his visit to Nigeria.

H. LEHMANN

St. Bartholomew's Hospital, London. E.C.1.

$$
\text { C. Nwokolo }
$$

General Hospital, Enugu,

Eastern Nigeria. March 2.

${ }^{1}$ Fdington, G. M., and Lehmann, H., Man, 56, 34 (1956).

Cabannes, E., in "Abnormal Hromoglobins : a Symposium organized by the Council for the International Organizations of Medica Science, established under the joint auspices of Uneseo and W.H.O.", edit. by Jonxis, J. H. D. (Blackwell Scientific Publications, Oxford, in the press)

${ }^{3}$ Allison, A. C., Ann. Hum. Genet, , 21, 67 (1956).

4 Walters, J. H., and Lehmann, H., Trans. Roy. Soc. Trop. Med. Hyg., 50, 204 (1956).

${ }^{s}$ Garlick, J. D., and Barnicot, N. A., Ann. Hum. Genet., 21, 420 (1957).

' Roberts, D. F., and Lehmann, H., Proc. Symp. Genetie Hrematology, Istituto Mendel, Rome, 1958 .

7 Langouillon, J., and Delas, A., Méd. Trop. Marseilles, 17, 899 (1957).

Nwokolo, C., West African Med. J., 6, 123 (1957).

\section{Interaction between Ants on a Scent Trail}

IT is well known that many ants lay scent trails on the ground which can be followed by other ants ${ }^{1-8}$. When an ant is following such a trail it is guided primarily by the scent 'marks', although other orientating factors, including visual stimuli, are sometimes also involved ${ }^{2,4}$. Carthy ${ }^{3}$ has suggested that another factor contributing to the dense trails formed by Acanthomyops fuliginosus workers might be a tendency for workers to seek maximal contact with their companions. During a study of the trail systems of the ant Monomorium pharaonis ${ }^{4}$ it was possible to record the behaviour of successive workers arriving at a branch in the trail system, and to relate this to the behaviour of the preceding ant. At such a branch each ant took either branch $A$ or branch $B$, and if the proportion of all ants which took branch $A$ was $p$, the proportion which took $B$ would be $(1-p)$. If there were no relation between the 'choice' of one ant and that of the following ant the expected proportions of pairs of successive ants taking respectively $A$ and $A, A$ and $B, B$ and $A$ and $B$ and $B$ would be $p^{2}$, $p(1-p), p(1-p)$ and $(1-p)^{2}$. Table 1 shows that the observed proportions conform very closely with these figures and do not differ from them significantly in a $\chi^{2}$ test $\left(\chi^{2}=2.02\right.$ with 3 degrees of freedom, $P>$ 50 per cent).

Table 1. RELATION BETWEEN THE 'CHOICE' MADE BX ONE ANT BETWEEN TWO TRALL $A$ AND $B$ AND THE 'CHOICE' MADE BY THE FOLLOWING ANT. FIGURFS FOR ALT ANTS

\begin{tabular}{|c|c|c|c|c|c|c|c|}
\hline & \multicolumn{2}{|c|}{$A$} & \multicolumn{2}{|c|}{$B$} & \multicolumn{3}{|c|}{ TotaIs } \\
\hline Choi & $A$ & B & $A$ & $B$ & $A$ & $B$ & All \\
\hline $\begin{array}{l}\text { Observed n } \\
\text { Expected } \\
\text { Contributio }\end{array}$ & $\begin{array}{l}48 \\
52 \cdot 9 \\
0 \cdot 45\end{array}$ & $\begin{array}{l}63 \\
58 \cdot 1 \\
0 \cdot 43\end{array}$ & $\begin{array}{l}64 \\
58 \cdot 1 \\
0 \cdot 60\end{array}$ & $\begin{array}{l}58 \\
63.9 \\
0.54\end{array}$ & 112 & 121 & $\begin{array}{c}233 \\
(233)\end{array}$ \\
\hline
\end{tabular}

As the trails of Monomorium pharaonis are not very dense this result is not surprising. $M$. pharaonis were not, however, evenly distributed along the trails, but often ran close behind one another, perhaps simply because quicker ants caught up slower ones. When only such pairs of ants running almost if not quite in contact are considered, both ants of the pair took the same branch of the trail significantly more often than would have been expected if no interaction took place (Table 2, $\chi^{2}=6 \cdot 16$ with 1 degree of freedom, $P$ lies between 1 and 2 per cent). In Table 2 Table 2, RELATION BETWEEN THE 'CHOICE' MADE BY ONE ANT AND
THAT OF THE FOLLOWING ANT. FIGURES ONLY FOR THOSE ANTS RUNNING IN PAIR

\begin{tabular}{|c|c|c|c|}
\hline & $\begin{array}{l}\text { Chose the } \\
\text { same branch }\end{array}$ & $\begin{array}{c}\text { Chose different } \\
\text { branches }\end{array}$ & Total \\
\hline $\begin{array}{l}\text { Observed number } \\
\text { Expected number } \\
\text { Contribution to } \chi^{2}\end{array}$ & $\begin{array}{l}13 \\
8 \cdot 03 \\
3 \cdot 07\end{array}$ & $\begin{array}{l}3 \\
7 \cdot 97 \\
3 \cdot 09\end{array}$ & $\begin{array}{l}16 \\
16 \\
6 \cdot 16\end{array}$ \\
\hline
\end{tabular}

different grouping of the results was necessary because of the smaller numbers involved, but the method by which the expected distribution was calculated was the same as in Table 1. As well as the sixteen pairs on which Table 2 was based there were four groups of three ants and one of seven ants, but such small numbers do not allow any conclusions to be drawn.

Apparently in Monomorium pharaonis one ant does tend to follow the course taken by another provided that the two are running so close together as to be almost in contact. According to Hingston ${ }^{5}$ Camponotus sericeus and $C$. paria behave in a similar way. These ants, however, do not lay scent trails and the recruits reach newly discovered food by following its discoverer on the latter's return to the food from the nest. It seems possible that the traillaying behaviour of Myrmicine ants has evolved through such a stage where one ant led another directly, and it is therefore interesting to find traces of such behaviour in Monomorium pharaonis.

Department of Zoology,

J. H. SUDD*

University College,

Ibadan, Nigeria. March 6.

* Present address : Department of Zoology, University of Hull.

${ }^{1}$ Forel, A., "The Senses of Insects" (Methuen, 1908).

${ }^{2}$ Goetsch, W., $Z$, Morph. Oekol. Tiere, 28, 319 (1934)

${ }^{3}$ Carthy, J. D., Trans. Ninth Int. Congress Entomology, 1, 365 (1952).

${ }^{4}$ Sudd, J. H. (unpublished work). "Hingston, R. W. G., "Problems of Instinct and Intelligence" (Arnold,

\section{Mechanical Transmission of Cassava Brown Streak Virus}

Brown streak virus disease of cassava (Manihot utilissima Pohl.) is important in all the cassavagrowing areas on the coasts of Kenya and Tanganyika, because necrosis of the starch storage tissues of the roots and stems of infected plants results in serious losses in yield ${ }^{1,2}$. Transmission of the virus by a white fly (Bemisia sp.) is suspected but has not been confirmed ${ }^{\mathbf{s}}$ and the only reliable means of transmitting it experimentally has been by grafting. The symptoms of the disease vary greatly with variety and environmental conditions, making diagnosis difficult, particularly when plants are infected both with brown streak and casseva mosaic, another virus disease. Thus a major difficulty in studying brown streak has so far been the lack of a means of transmitting the causal virus readily and also uncontaminated with cassava mosaic virus.

A virus causing typical brown streak symptoms in cassava seedlings has now been transmitted mechanically from cassava to several solanaceous plants. Mature leaves from infected cassava plants were macerated in water with alumina powder and 'Celite' and the extract inoculated by rubbing on the leaves of various test plants. Using this method, virus was readily transmitted to susceptible test plants, but similar extracts from young leaves gave no infections. 